\title{
Patterns and processes of brachyuran crab settlement to Caribbean coral reefs
}

\author{
Nathalie Reyns*, Su Sponaugle* \\ Marine Sciences Research Center, State University of New York, Stony Brook, New York 11794-5000, USA
}

\begin{abstract}
Many workers have examined the processes influencing the recruitment of temperate marine invertebrates but comparatively little is known about their tropical counterparts. Brachyuran crustaceans are important constituents of coral reefs, yet remain largely under-studied. To examine the temporal patterns of tropical brachyuran larval abundances and postlarval settlement, we deployed 3 replicate light traps nightly for 7 mo (May to November 1996) at Barbados, West Indies. Wind data and tidal and large-scale flow due to currents were measured concurrently. Light traps collected a total of 320896 zoeae (all stages and families combined) and 452741 megalopae dominated by the families: Maidae, Xanthidae, Grapsidae, and Portunidae. While overall abundances of first-stage zoeae remained continuous over the sampling interval, postlarval settlement was more variable. Using time series analysis, periodicity in the larval and postlarval abundances was identified as: first-stage zoeae, 29 d; Majidae postlarvae, 31 d; Xanthidae postlarvae, 15 d; Grapsidae postlarvae, 28 d and Portunidae postlarvae, 21 to $22 \mathrm{~d}$. We analyzed temporal patterns of zoeal abundance and megalopal settlement with respect to cyclical environmental cues as well as the mean daily wind and ambient current regime. Larval abundance was associated with the first quarter moon and minimum amplitude tides, while postlarvae were generally more abundant on the third quarter moon. Majidae postlarvae were distributed over a relatively broad period of the lunar cycle, encompassing 3 peaks occurring during the quarter moons and new moon. This pattern likely results from a strong correlation between Majidae postlarval settlement and ebb tides occurring in complete darkness. Xanthidae and Grapsidae postlarval settlement occurred predominately during the third quarter moon and intermediate to minimum amplitude tides. Postlarval abundances of these families were most tightly correlated to the maximum daily tidal range. Only Portunidae postlarvae were not influenced by proximate environmental cues such as the lunar and tidal amplitude cycles. During the study, wind was nearly consistently from the nor theast, while data from an offshore current meter demonstrated that the current flowed predominately toward the north. In general, patterns of larval abundance and postlarval settlement were not as closely correlated to the wind and ambient currents as to the proximate environmental cues such as hours of darkness and the tidal cycle. We propose that cyclical environmental parameters are likely important cues to coastal species living in highly dynamic physical environments.
\end{abstract}

KEY WORDS: Tropical crabs - Megalopae - First-stage zoeae - Larval supply - Settlement - Environmental cues · Tides

\section{INTRODUCTION}

It is widely accepted that the recruitment of marine invertebrates is highly variable (reviewed in Booth \& Brosnan 1995), causing temporal and spatial fluctua-

\footnotetext{
- Present address: Rosenstiel School of Marine and Atmospheric Science, Division of Marine Biology and Fisheries, University of Miami, 4600 Rickenbacker Causeway, Miami, Florida 33149, USA. E-mail: nreyns@rsmas.miami.edu
}

tions in adult populations and community dynamics. Determining the biological and physical processes that influence recruitment has been the focus of considerable research, particular.y for temperate marine invertebrates associated with rocky intertidal communities (e.g. Paine \& Levin 1981, Gaines \& Bertness 1992, reviewed in Booth \& Brosnan 1995) and those inhabiting estuarine embayments (e.g. Epifanio 1988a,b, Eggleston \& Armstrong 1995, van Montfrans et al. 1995, Eggleston et al. 1998). With the exception of sev- 
eral highly visible taxa (e.g. echinoderms, Black \& Moran 1991; corals, Wolanski et al. 1989) and commercially important species (e.g. queen conch, Stoner et al. 1997, Stoner \& Smith 1998; spiny lobsters, Yeung 1996. Acosta et al. 1997), the recruitment dynamics of tropical marine invertebrates has received substantially less attention. Brachyuran crustaceans are diverse and important constituents of tropical reef communities (Reed et al. 1982), but remain relatively under-studied due to their cryptic nature (Sebens 1984, Lewis \& Snelgrove 1990). As a result, little is known about patterns of larval production and settlement of tropical crabs, or the biological and physical processes underlying these patterns.

The importance of cyclical environmental cues to the production of brachyuran crabs is evident from studies of terrestrial, semiterrestrial, and intertidal crabs living in temperate and subtropical regions. For these species, the timing of larval release is cued to such rhythmic environmental parameters as the lunar, tidal, and light-dark cycles (Barnwell 1976, Forward 1987, Morgan \& Christy 1994, Morgan 1995). Entrainment of these rhythms is thought to be selectively advantageous for females who must migrate to the water's edge for larval release, and to the larvae that must be transported away from predator-rich coastal areas (Morgan 1995). For subtidal crabs, entrainment of the tidal amplitude and light-dark cycle is less synchronous. Maximum amplitude tides and darkness are not likely important selective pressures on females who need not walk to water for larval release (Morgan 1995). However, larval survival of these subtidal species may be enhanced if they are rapidly transported away from coastal areas on nocturnal ebb tides (Christy 1986). Thus, for species that are exported from inshore habitats, larval release often occurs during the new and full moons around the time of high tide, and during the first few hours of darkness.

Cyclical environmental parameters are clearly important to the timing of larval release (reviewed in Morgan 1995), but may also be used by temperate estuarine crabs during other stages of the life cycle. This has been well documented for several species (e.g. the xanthid Rhithropanopeus harrisii, Cronin \& Forward 1983, the ocypodid Uca spp., Epifanio et al. 1988, and the portunid Carcinus maenas, Zeng \& Naylor 1996), with the best known example being the commercially important portunid blue crab Callinectes sapidus (Epifanio et al. 1984, Tankersley \& Forward 1994, van Montfrans et al. 1995). In the Chesapeake and Delaware Bays, female blue crabs, presumably using tidal stream transport, migrate to estuary mouths where larvae are released near the time of high tide (Provenzano et al. 1983, Epifanio et al. 1984). Larvae are transported offshore to the continental shelf where development occurs in high salinity waters and the risk of predation decreases. Megalopae are concentrated in surface waters by reverse diel vertical migrations and are transported back to estuary mouths by winddriven surface currents (McConaugha et al. 1983, Johnson 1985, Goodrich et al. 1989). Postlarvae use selective tidal stream transport to re-invade the estuary (Epifanio 1988a, DeVries et al. 1994, Olmi 1994, Tankersley \& Forward 1994) and settle with semi-lunar periodicity (van Montfrans et al. 1995)

Much less is known about the environmental cues influencing the reproductive and recruitment patterns of tropical species. The life cycle of a tropical estuarine portunid Callinectes arcuatus is believed to be similar to that of Callinectes sapidus (DeVries et al. 1983). Gravid females migrate to estuary mouths to insure that zoeae develop in high salinity waters offshore (DeVries et al. 1983, Dittel et al. 1985). Although postlarval abundances were not examined in either of these studies, it was suggested that megalopae would likely reinvade the estuary using similar mechanisms as C. sapidus (DeVries et al. 1983, Dittel et al. 1985).

In addition to the cyclical environmental cues often used by estuarine species, the supply and settlement of some brachyuran crab larvae have been linked to various oceanographic features. For example, settlement patterns of temperate, coastal brachyurans have been correlated with upwelling (Botsford \& Wickham 1975), the relaxation of upwelling favorable winds (Wing et al. 1995), and tidally forced internal waves (Shanks 1985, 1995a). More recently, Leichter et al. (1998) documented the transport of crab zoeae, copepods, serpulid worms and fish larvae onto a Florida reef tract by internal tidal bores. Larval behavior may be coupled with such oceanographic processes to influence the patterns of brachyuran recruitment. For instance, based on the relative position of megalopae in the water column, Shanks (1998) suggested shoreward transport of postlarvae was due to tidally driven processes for Callinectes sapidus, regional upwelling for a majid, Libinia spp., and wind-driven surface currents for the ocypodid Uca spp.

While proximate environmental cues and oceanographic processes combined with larval behavior likely influence patterns of recruitment, the relationship between these biological and physical factors remains unclear for tropical brachyuran crabs. Thus, we sought to identify the temporal patterns of tropical brachyuran larval abundance and settlement and to ascertain which proximate environmental cues influence the nearshore supply of brachyuran larvae. We designed the study to identify whether cyclical environmental parameters or oceanographic processes play a greater role in determining patterns of tropical brachyuran crab larval abundance and settlement. 


\section{MATERIALS AND METHODS}

Site description. Barbados is a small ( 15 by $25 \mathrm{~km}$ ), coral-limestone island located $140 \mathrm{~km}$ to the east of the Lesser Antilles $\left(13^{\circ} 10^{\prime} \mathrm{N} 59^{\circ} 30^{\prime} \mathrm{W}\right.$; Fig. 1). As the easternmost island in the Caribbean, Barbados lies within the path of the northeast trade winds (attaining speeds of $5 \mathrm{~m} \mathrm{~s}^{-1}$, Stansfield 1995). Barbados is geographically isolated and upstream from other sources of coral reef larvae. Therefore, it is generally believed that larvae collected in the surrounding waters are spawned from local populations (Cowen \& Castro 1994, Sponaugle \& Cowen 1996a).

Large-scale circulation around Barbados appears to be topographically steered, with nearshore current speeds reduced relative to offshore flow due to frictional forces (Cowen \& Castro 1994). Along the western (leeward) coast, currents predominately flow in the north-south direction, with relatively less east-west flow. However, in this area, variations of the east-west tidal flow may create striking spatial differences in the patterns of larval supply (Sponaugle \& Cowen 1996a). The local semi-diurnal tidal regime is characterized by 2 low and 2 high tides, each of varying tidal amplitude (Barnwell 1976). Nightly maximum amplitude tides are associated with or just after new and full moons and minimum amplitude tides are associated with or just

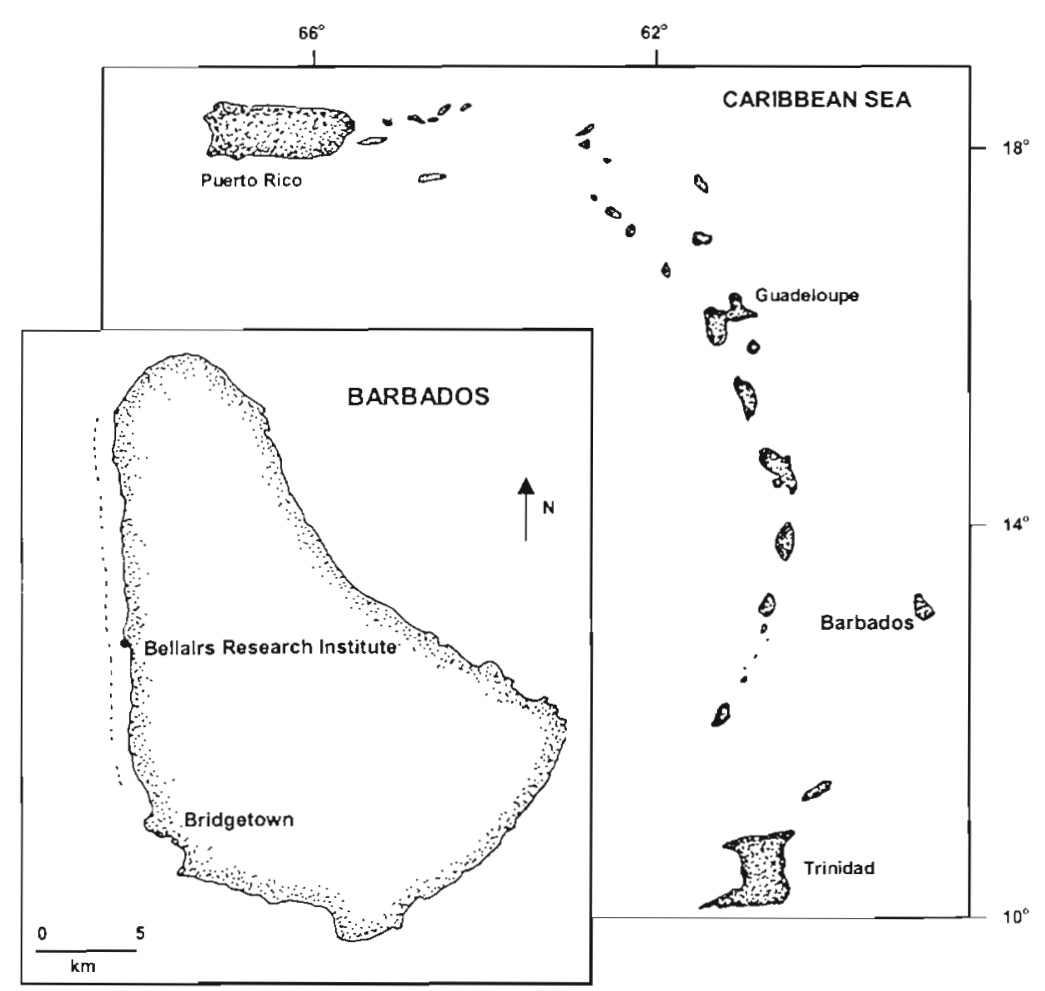

Fig. 1. Map of Barbados showing the sampling site (•). The current meter was deployed just offshore of the sampling location. The dashed line represents the deep fringing bank reef approximately $1 \mathrm{~km}$ offshore after quarter moons (Reyns 1998). The tidal amplitude cycle and the lunar cycle remain closely coupled during the spring, summer, and fall months (Sponaugle \& Cowen 1996a,b, Reyns 1998).

The west coast of Barbados is fringed by a shallow (1 to $15 \mathrm{~m}$ depth), nearshore coral spur and groove reef system. Reef spurs composed predominately of dead coral matrix (Sponaugle \& Cowen 1997) are concentrated at small headlands and are separated by narrow sand or sand-rubble channels which extend offshore to the deeper, sandy benthos. Approximately $1 \mathrm{~km}$ offshore, a bank reef parallels the coast, rising from a depth of 40 to $50 \mathrm{~m}$ to approximately 15 to $20 \mathrm{~m}$.

Biological sampling. Sampling was conducted at a central site along the west coast of Barbados (off of the Bellairs Research Institute, Holetown; Fig. 1). To examine the temporal patterns of larval abundance and settlement of brachyuran crabs, we deployed 3 replicate larval light traps nightly for 7 continuous months in 1996. Light traps were approximately $1 \mathrm{~m}$ in length and were equipped with a $6 \mathrm{~W}$ fluorescent bulb which remained lit for a period of 10 to $12 \mathrm{~h}$ (see Sponaugle \& Cowen 1996a for detailed description). We used light traps to sample for crabs because previous work demonstrated that they were effective at providing both a measure of larval supply (by collecting firststage zoeae, the first larval stage), and a measure of settlement (by collecting megalopae, the postlarval stage presumably nearing settlement; S. S. unpubl. data). In addition, light traps collected a representative assemblage of brachyurans present in the surrounding waters (based on concurrently collected plankton samples; N. R. \& Cowen unpubl. data). A concurrently deployed array of standard 'hogs-hair' settlement substrates (as used extensively along the Atlantic and Gulf Coasts, e.g. Rabalais et al. 1995, van Montfrans et al. 1990, 1995) failed to collect megalopae (N. R. unpubl. data).

We anchored light traps approximately $150 \mathrm{~m}$ off of the nearshore reefs in $10 \mathrm{~m}$ of water such that the tops of the traps were suspended $2 \mathrm{~m}$ below the surface to avoid boat traffic. Traps were separated by $40 \mathrm{~m}$ and arranged in a north-south orientation, parallel to the nearshore reef. We deployed light traps nightly at sunset and retrieved them at sunrise from May 1 until November 30, 1996. Upon retrieval, we rinsed the light traps, split the collections to fit into $25 \mathrm{ml}$ jars using a Folsom plankton splitter, and preserved the sample in $95 \% \mathrm{EtOH}$ for further processing and identification. 
Zoeae and megalopae were identified to the lowest possible taxonomic level.

Physical sampling. To examine the physical processes influencing the nearshore larval and postlarval supply, we collected environmental and oceanographic data concurrently with light trap deployment. Currents, tidal height, and wind data were compiled for as large a portion of the biological time series as possible.

Wind direction and speed were measured and made available by the Caribbean Meteorological Institute. Wind data were measured on top of Holder's Hill (Husbands, St. James) located along the west coast of Barbados, approximately $5 \mathrm{~km}$ from the site of biological sampling. We computed the east-west (u-) and northsouth ( $\mathrm{v}$-) components of the wind velocity, and then calculated the mean wind velocity each day.

Currents were measured by an offshore moaring equipped with an upward-looking Acoustic Doppler Current Profiler (ADCP; Kelly et al. in press). The mooring was deployed from May 12 to August 1, 1996 and again from August 23 to November 12 in approximately $290 \mathrm{~m}$ of water, $1 \mathrm{~km}$ off of Holetown. The ADCP was configured to continuously measure current velocities at 7 depth bins $(16,24,32,40,48,56$, $64 \mathrm{~m}$ ) in $10 \mathrm{~min}$ intervals. We chose to analyze the flow from the $32 \mathrm{~m}$ depth bin because nearshore vertical distribution data from a separate study demonstrated that megalopae of most families are concentrated between 20 to $40 \mathrm{~m}$ depth (N. R. \& Cowen unpubl. data). We separated current velocities into u- and vcomponents, and then band-passed the data to separate out flow due to tides. We applied a high-pass filter with an $8 \mathrm{~h}$ cut off period to remove low frequency signals, followed by a low-pass filter with a $34 \mathrm{~h}$ cut off period to remove frequencies greater than $34 \mathrm{~h}$ (just over the length of the daily tidal period). We also examined the flow due to episodic or large-scale events and inertial currents by low-pass filtering the raw components with a standard $72 \mathrm{~h}$ cut off period (K. Lwiza, SUNY Stony Brook pers. comm.). All filtering was performed using the 'filtfilt' function in the computer program, MATLAB (The Math Works, Bothell, WA). Subsequent to filtering, we calculated the integrated $24 \mathrm{~h}$ transport (i.e. from 06:00 to 06:00 h, encompassing the sampling period).

Statistical analyses. Due to difficulties identifying zoeae to the family level, individuals were grouped only by stage (all families combined) for analysis. We present the first-stage zoeae record as a measure of relative larval abundance. Due to the large diversity and high numbers of postlarvae collected, we confined our analysis of temporal settlement patterns to the family level, and only report patterns for the most abundant families. However, cursory examination of the raw settlement records of all collected species revealed that most minor taxa exhibited settlement patterns similar to those of the families presented here (Reyns 1998).

A large peak occurring at the start of the time series characterized the raw settlement records for the postlarval Majidae, Xanthidae, and Grapsidae. However, a fundamental problem with collecting time series data is that little is usually known regarding the events occurring immediately prior to and following the sampling period (H. Deferrari, RSMAS pers. comm.). Thus, the sampling interval should be tapered to reduce the influence of large peaks found on either end of the time series as well as to decrease the leakage from strong components when conducting times series analyses (Bloomfield 1976; H. Deferrari, RSMAS pers. comm.). To accomplish this, a split-cosine bell function was applied to $10 \%$ ( $5 \%$ at either end) of each settlement time series to taper the data window (Bloomfield 1976).

Cyclical patterns of abundance: To determine whether the larval and postlarval abundances varied in a cyclical nature, the autocorrelation function (ACF) was computed for each abundance record. The ACF is a time series analysis tool that identifies cyclic behavior in the time domain (Jassby \& Powell 1990). For the abundance records that varied with a period near 15 or $29 \mathrm{~d}$ (see 'Results'), we examined the biological data relative to 2 cyclical environmental parameters which have similar periods: the lunar and tidal amplitude cycles. We assigned the mean number of larvae and postlarvae collected nightly per trap, to a lunar day ('Lunar Day 1' representing the night of the new moon) and a tidal day ('Tidal Day 1' equivalent to the night closest to the new moon with maximum nocturnal amplitude tides). The lunar and tidal days were summed over the duration of the study, and then collapsed into a single $29.7 \mathrm{~d}$ lunar cycle and a single 29.4 d tidal amplitude cycle. We used Rayleigh circular statistics to determine whether larval abundance and settlement were uniformly distributed over these cycles (Batschelet 1981, Zar 1984). Where the Rayleigh test indicated non-random settlement, we calculated the mean lunar day or mean tidal day (the day of the lunar or tidal amplitude cycle about which the data were distributed).

Temporal patterns of larval supply and postlarval settlement may, in fact, be linked to a combination of the lunar and tidal amplitude cycles which also vary with periods of approximately $30 \mathrm{~d}$ (or $15 \mathrm{~d}$, i.e. the semi-lunar period or fortnightly tidal cycle). Thus, using tidal height data we calculated the number of nightly flood (increasing change in tidal height over time) and ebb (decreasing change in tidal height over time) hours, as well as the maximum amplitude tidal 
range (the maximum change in tidal height between high and low tide). In addition, we calculated the number of dark (prior to moonrise or after moonset) and moonlit flood and ebb hours using moonrise and moonset data from the Astronomical Application Department of the U.S. Naval Observatory. Because the moon phase changes nightly, we used a Lunar-Illumination Fraction (L.I.F., where $1=$ full moon and $0=$ new moon; computed from charts provided by the Astronomical Application Department of the U.S. Naval Observatory) to determine relative darkness during moonlit periods.

Using the tidal height data, the hours of moonrise and moonset, and the L.I.F., we estimated the following proximate environmental parameters:

(1) 'hours of darkness' $=$ the number of hours between sunset and sunrise without moonlight;

(2) 'moonless' flood/ebb hours $=$ the number of flood/ebb hours occurring in complete darkness;

(3) 'moon-illuminated' flood/ebb hours $=$ (flood/ebb hours occurring in moonlight) (1 - L.I.F.).

We calculated these parameters, as well as the maximum tidal range for the entire night (from 18:00 to 06:00 h).

Cross-correlations: We used cross-correlation analysis to examine the relationship between the abundance data and the proximate environmental parameters. To account for significant autocorrelation present in the abundance and environmental time series, we calculated confidence intervals that accounted for this intraseries correlation (Wing et al. 1995). We used this value corrected for autocorrelation to specify significance when it was more conservative than the confidence intervals calculated by standard cross-correlation analysis.

To examine how ambient currents and wind were related to patterns of larval supply and postlarval settlement, autoregressive moving average (ARMA) models were fitted to the abundance and physical time series. ARMA modeling removes periodicity and autocorrelation, reducing the data to 'white noise' (Chatfield 1989, Dunstan 1993). The residuals (or 'white noise') of each modeled series can then be cross-correlated and examined for relationships (Dunstan 1993). Model orders were selected according to the Schwarz criterion, and residuals were checked with a $\chi^{2}$ test for white noise and visually inspected to make sure no autocorrelations were present (Dunstan 1993).

All ARMA models and cross-correlations were performed using the statistical software Minitab (Minitab, Inc.). Only correlation coefficients significant at $\mathrm{p}<0.05$ are reported. We computed cross-correlations for lags of up to $6 \mathrm{~d}$, where lags reflect the number of days larvae and postlarvae peaked after environmental events.

\section{RESULTS}

\section{Temporal patterns of larval abundance and postlarval supply}

Although the response of crabs to particular environmental and physical cues is likely species-specific, we report the patterns at the family level. Not only did cursory examination of species-specific patterns demonstrate that the majority of species exhibited similar family-wide patterns, but since very little is known about the ecology of tropical brachyuran crabs, results of this study represent a first step towards understanding the life history dynamics of tropical crabs and their interactions with the physical environment.

Light traps proved to be effective devices for sampling megalopae of a diversity of brachyuran crabs, while also providing a measure of larval abundance. A total 320896 zoeae (all stages combined) and 452741 megalopae were collected. Fifty-six postlarval species and morpho-types were identified comprising at least 7 families, although only the records of the 4 most abundant families are presented: Majidae, Xanthidae, Grapsidae, and Portunidae, respectively (Table 1).

First-stage zoeae were produced nearly continually and often in distinct pulses throughout the 7-mo sampling season (Fig. 2). Patterns of postlarval supply generally exhibited monthly variability, with family-wide trends in settlement. Postlarval crabs in the Majidae, Xanthidae, and Grapsidae families were characterized by a distinct pulse during the first month of sampling (Days 120 to 130 ), a subsequent decrease in the magnitude of pulses during the summer months (Days 140 to 240), followed by an increase of pulses during the last several months (Days 240 to 330; Fig. 2). Although the Portunidae megalopae exhibited a similar overall settlement pattern, pulses were more episodic in nature (Fig. 2).

Table 1. Abundances of brachyuran larvae and postlarvae collected from May 1 to November 30, 1996 in light traps off of Barbados, W.I. Families are listed in order of abundance. The number of identified species and/or morpho-types comprising each family are listed in parentheses

\begin{tabular}{|lc|}
\cline { 2 - 2 } Family & Abundance \\
\hline First-stage zoeae & \\
(all families combined) & 256550 \\
Majidae postlarvae (9) & 325182 \\
Xanthidae postlarvae (2) & 70874 \\
Grapsidae postlarvae (4) & 18734 \\
Portunidae postlarvae (2) & 10139 \\
Unidentified postlarvae & 19478 \\
\hline
\end{tabular}



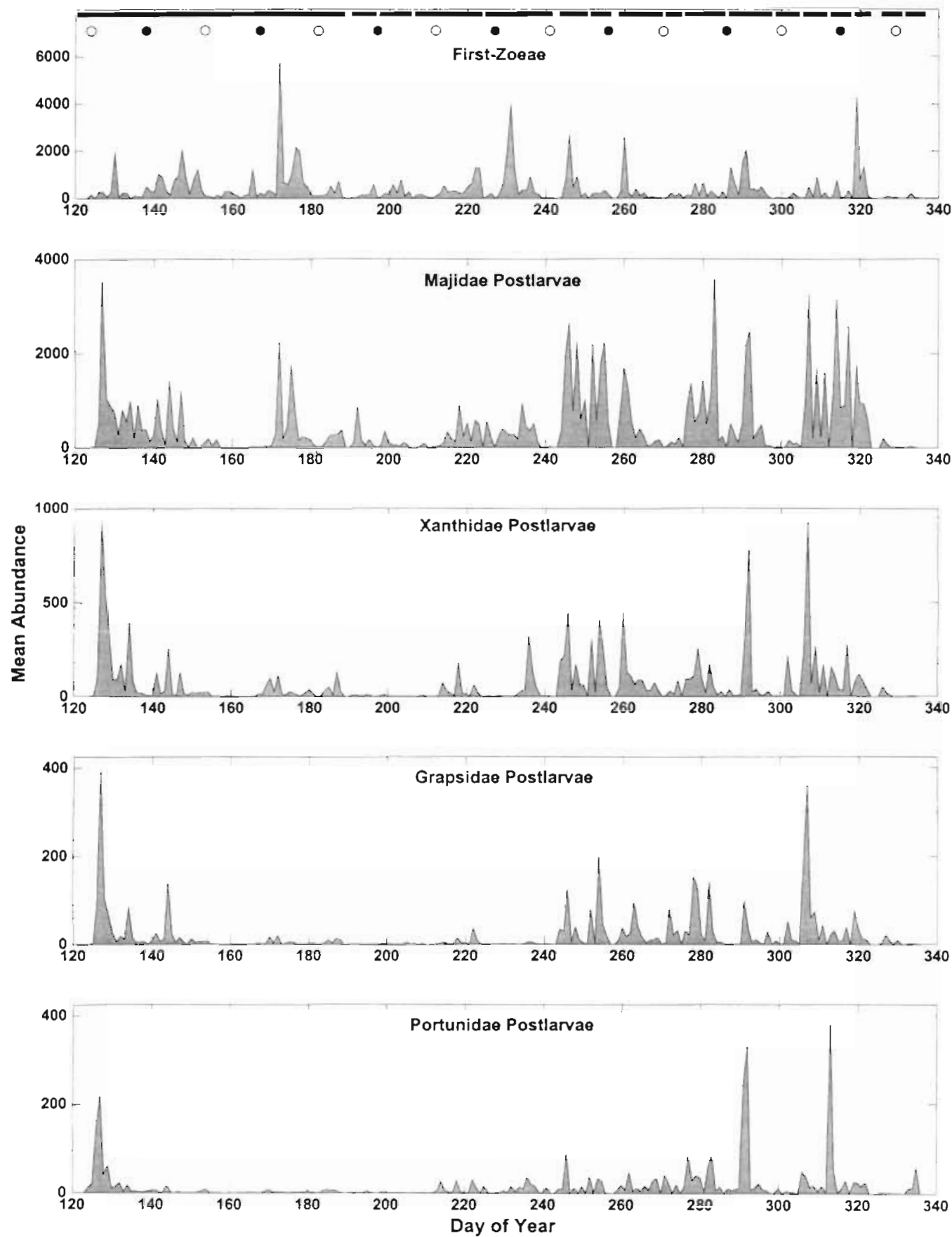

Fig. 2. Mean abundance record of the split-cosine bell tapered abundance data collected in 3 replicate light traps. The shaded bar at the top of the upper panel represents the days sampled, while the open and closed circles represent the full and new moons, respectively

\section{Monthly periodicity in larval abundance and postlarval supply}

Analysis of the autocorrelation functions identified significant periodicity in the first-stage zoeae and settlement records. First-stage zoeae as well as postlarval majids and grapsids were characterized by a $\sim 29 \mathrm{~d}$ period, (Fig. 3). Xanthid abundances exhibited a $15 \mathrm{~d}$ cycle, while portunids exhibited an unusual 21. to $22 \mathrm{~d}$ settlement period (Fig. 3).
Lunar and tidal amplitude cycles

First-stage zoeae and the postlarval records for the Majidae, Xanthidae, and Grapsidae exhibited periodicity characteristic of the lunar and tidal amplitude cycles. Thus, these distributions were analyzed over both environmental cycles using Rayleigh circular statistics. First-stage zoeae and all postlarvae exhibited non-random distributions with respect to the lunar and tidal amplitude cycles (Table 2). Supply of first-stage 

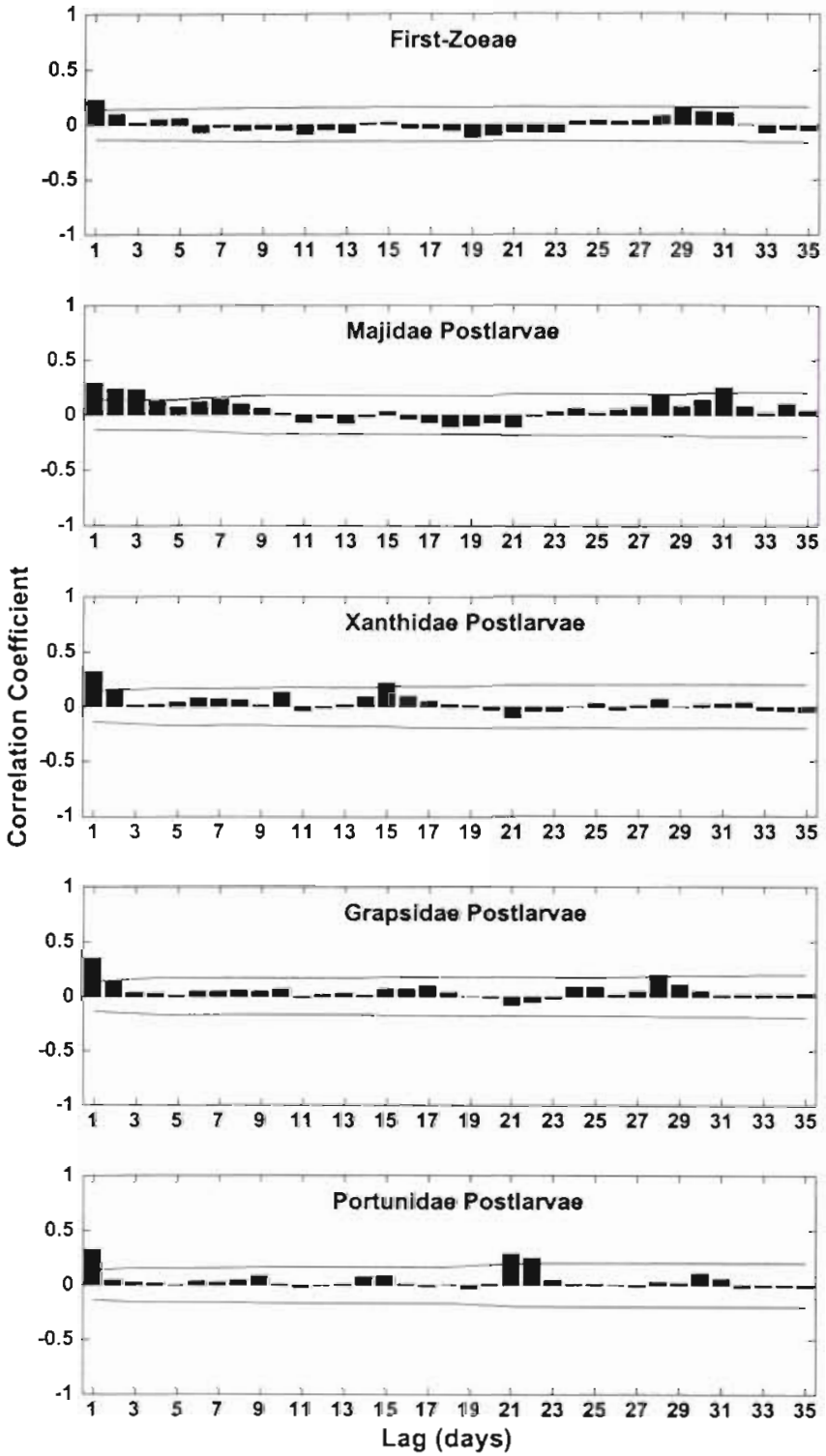

Fig. 3. Autocorrelation functions showing the periodicity of the split-cosine bell tapered abundance data. Lines represent the $95 \%$ confidence intervals around the quarter moons, with the largest mode centered on the third quarter moon and during periods of minimum amplitude tides (Table 2, Fig. 4). Overall, larval abundance and postlarval settlement occurred primarily during quarter moons and intermediate to minimum amplitude tides.

\section{Proximate environmental cues}

To further distinguish the proximate environmental cues associated with the lunar and tidal amplitude cycles, we examined the correlations between larval and postlarval abundances and the flood/ebb tide and light-dark cycle parameters. Abundances of first-stage zoeae and other postlarvae were significantly related to several variables. The strongest correlations between each abundance record and the proximate environmental cues were determined by the correlation coefficient, but also by examining the lag. For instance, the first-stage zoeae were more strongly correlated with moon-illuminated flood hours but at a longer lag than the correlation between larval abundance and moon-illuminated ebb hours whose coefficient is only slightly smaller (Table 3). Thus, the abundance of first-stage zoeae was considered to be more closely correlated to the hours of moon-illuminated ebb tide (Table 3, Fig. 5). The measure of hours of moon-illuminated ebb tide includes an index of relative darkness, and the importance of darkness is apparent in the correlation with hours of darkness (Table 3). For the Majidae postlarvae, darkness was also important where the strongest correlations were with the hours of moonless ebb tide and the hours of darkness, respectively (Table 3, Fig. 5). In contrast, Xanthidae and Grapsidae postlarvae were most tightly correlated with the maximum daily tidal range (Table 3, Fig. 5). zoeae peaked during the first quarter moon and intermediate amplitude tides (Fig. 4). In contrast, most postlarvae settled during the third quarter moon and intermediate to minimum amplitude tides (Fig. 4). Majidae megalopae settled over a broad period of the lunar cycle, encompassing 3 peaks occurring during the quarter moons and new moon (Fig. 4). Majidae settlement occurred during intermediate to minimum amplitude tides (Fig. 4). For the Xanthidae and Grapsidae postlarvae, settlement was bimodal
Table 2. Rayleigh test statistics for lunar and tidal amplitude cycles. All Z-values (Rayleigh test statistic, Batschelet 1981) presented are significant at $p<0.001$. Mean lunar/tidal day refers to the mean day about which the data are distributed, where Lunar Day 1 = new moon, and Tidal Day $1=$ maximum amplitude tides. In the case of bimodal distributions, 2 mean days are reported, with the mean day of the primary mode denoted in bold

\begin{tabular}{|c|c|c|c|c|c|}
\hline \multirow{2}{*}{ Family } & \multirow{2}{*}{$\begin{array}{c}\mathrm{n} \\
(\text { mean) }\end{array}$} & \multicolumn{2}{|c|}{ Lunar cycle } & \multicolumn{2}{|c|}{ Tidal amplitude cycle } \\
\hline & & $z$ & $\begin{array}{c}\text { Mean } \\
\text { lunar day }\end{array}$ & $Z$ & $\begin{array}{l}\text { Mean } \\
\text { tidal day }\end{array}$ \\
\hline First-stage zoeae & 85518 & 8515 & 6 & 8651 & 4 \\
\hline Majidae postlarvae & 107963 & 5868 & 27 & 5834 & 5,23 \\
\hline Xanthidae postlarvae & 23877 & 564.5 & 6,22 & 5301 & 6,22 \\
\hline Grapsidae postlarvae & 6284 & 1856 & 7,22 & 1608 & 6,20 \\
\hline
\end{tabular}



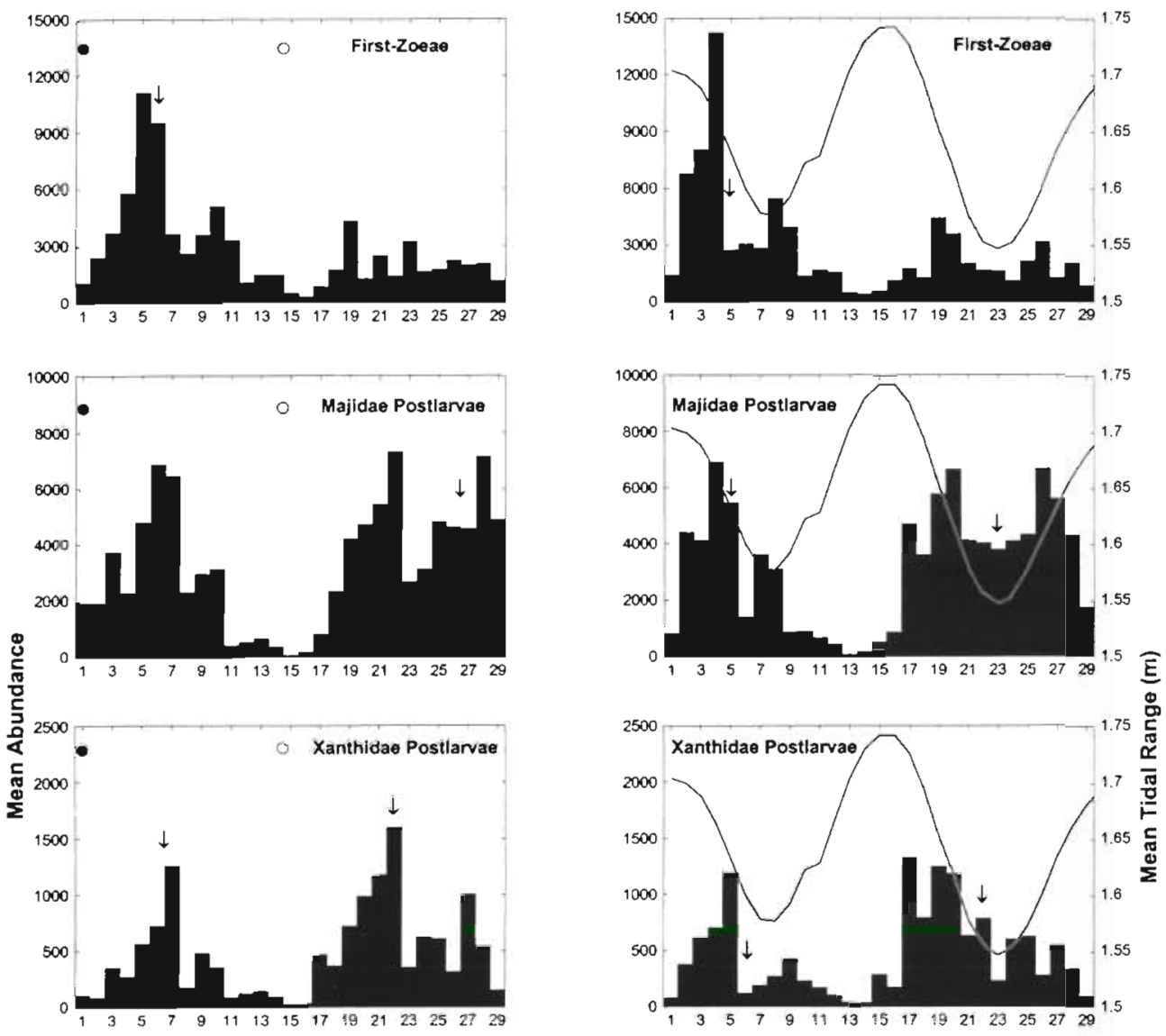

Fig. 4. Distribution of brachyuran crab larval abundance and postlarval
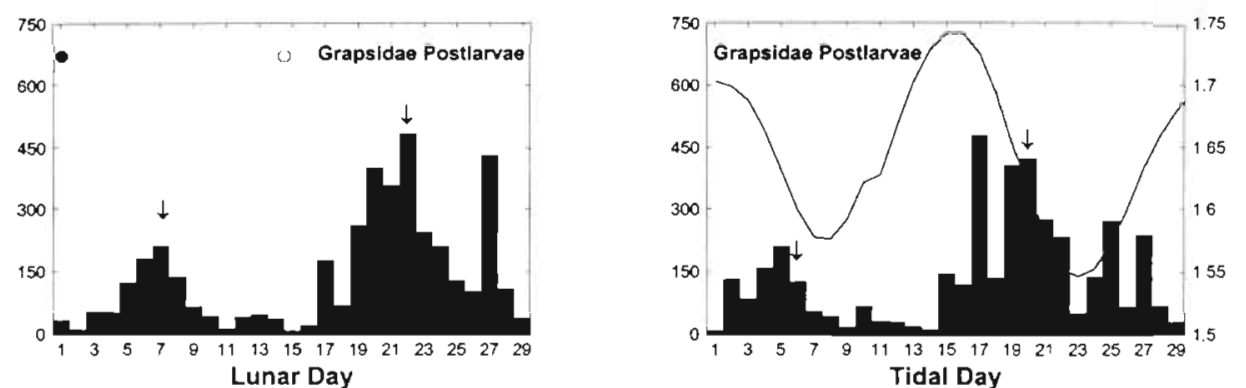
settlement over the lunar (left panels) and tidal amplitude cycle (right panels). Closed and open circles represent the new and full moons, respectively, and the lines represent the mean maximum tidal amplitude. Arrows indicate the mean day about which the data were distributed

Table 3. Cross-correlations between abundance of larvae and postlarvae with proximate environmental cues. All correlation coefficients presented are significant at $p<0.05$, unless otherwise noted (ns: not significant). Values in parentheses represent the lag in days (i.e. the number of days the larvae or postlarvae lag an environmental event; a lag of $-1 \mathrm{~d}$ interpreted as larvae peaking $1 \mathrm{~d}$ prior to the environmental event). Correlation coefficients presented are the maximum in a peak usually encompassing $\pm 3 \mathrm{~d}$. Most significant correlations denoted in bold

\begin{tabular}{|c|c|c|c|c|}
\hline $\begin{array}{l}\text { Proximate cues } \\
\text { (h/night) }\end{array}$ & $\begin{array}{c}\text { First-stage } \\
\text { zoeae }\end{array}$ & $\begin{array}{l}\text { Majidae } \\
\text { postlarvae }\end{array}$ & $\begin{array}{l}\text { Xanthidae } \\
\text { postlarvae }\end{array}$ & $\begin{array}{l}\text { Grapsidae } \\
\text { postlarvae }\end{array}$ \\
\hline Hours of darkness & $0.28(4)$ & $0.28(-2)$ & ns & $-0.19\{5\}$ \\
\hline Total flood & $0.22(6)$ & $-0.21(-2)$ & $-0.16(-2)$ & $-0.15(-2)$ \\
\hline Total ebb & $0.22(-3)$ & $0.21(-2)$ & $0.15(-2)$ & $0.14(-2)$ \\
\hline Moonless flood & $0.26(5)$ & $0.23(-3)$ & $0.17(-6)$ & $0.22(-6)$ \\
\hline Moonless ebb & $0.20(4)$ & $0.30(-2)$ & ns & $-0.17(5)$ \\
\hline Moon-illuminated flood & $0.32(-4)$ & $-0.23(4)$ & $-0.16(5)$ & $-0.17(-6)$ \\
\hline Moon-illuminated ebb & $0.29(-1)$ & $0.19(2)$ & $-0.20(6)$ & $-0.20(6)$ \\
\hline Tidal range & $-0.21(-3)$ & $-0.22(-2)$ & $-0.21(-4)$ & $-0.26(-3)$ \\
\hline
\end{tabular}



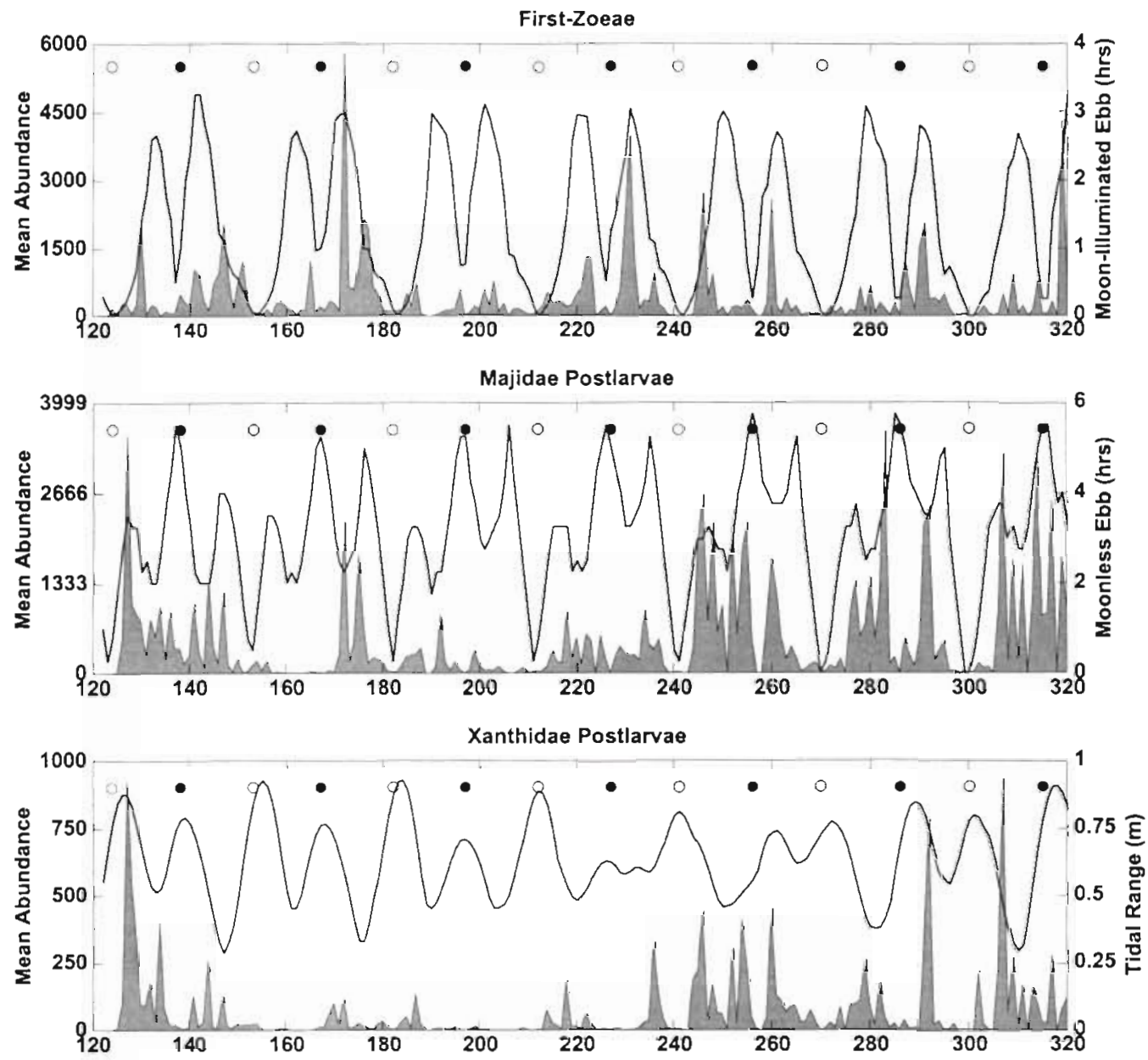

Fig. 5. Relationships between the abundance data (shaded series) and proximate environmental cues (thick lines) according to the strongest correlations (from Table 3). Open and closed circles represent the full and new moons, respectively

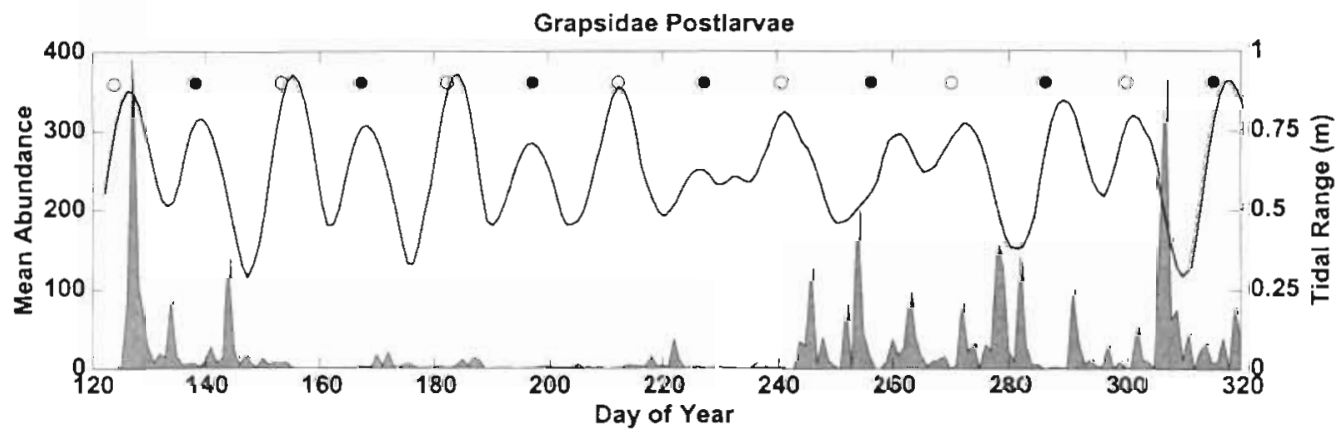

\section{Physical processes}

\section{Correlations with wind}

Not surprisingly, the winds were predominately from the northeast, with the exception of 1 directional reversal on Day 240, during which a small peak toward the east and relatively large peak toward the north are evident in the wind record (Fig. 6). Overall, abundances of first-stage zoeae and postlarvae were only weakly correlated with the wind components (Table 4).
Correlations with currents 

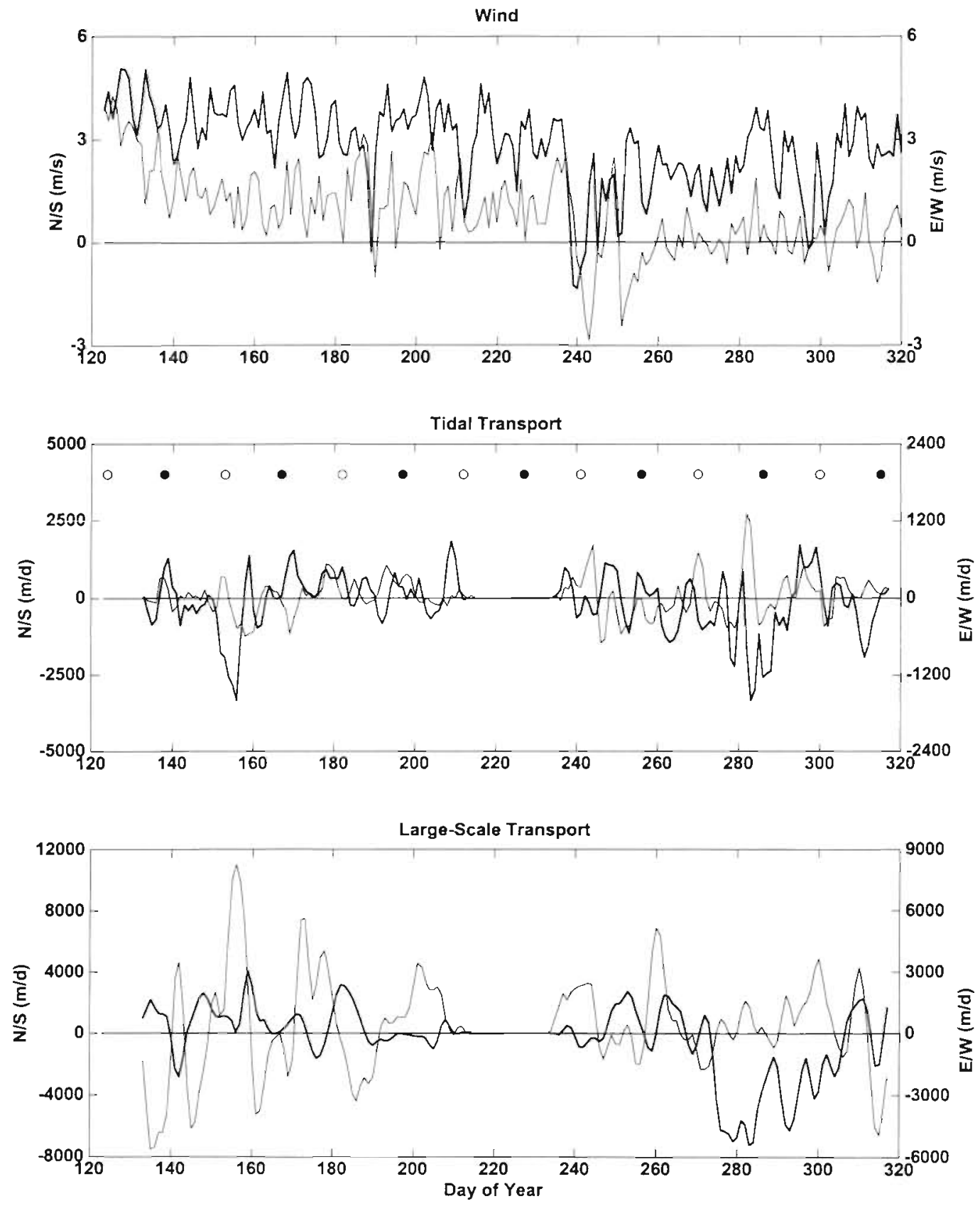

Fig. 6. Wind and current meter records from Barbados, WI. Thin lines: north-south, Thick lines: east-west. Open and closed circles represent the full and new moons, respectively. Wind velocities from the north and east are positive while transport by currents to the north and east are positive. All current meter records have been smoothed with a $3 \mathrm{~d}$ moving average for presentation purposes only

be real as larvae and postlarvae should consistently track the same oceanographic features over time. First-stage zoeae were not correlated with any component of transport measured by the current meter (Table 4). Correlations between settlement and transport due to tidal and large-scale currents were generally weak (Table 4). Only the Grapsidae were negatively correlated with north-south tidal transport over both mooring deployments, however the lag switches between the 2 deployments (from $-5 \mathrm{~d}$ to $6 \mathrm{~d}_{\mathrm{i}}$ Table 4).

\section{DISCUSSION}

Variability in the recruitment of benthic marine organisms is generally accepted, but the processes creating this variability are poorly understood. Examining how biological and physical factors contribute to fluctuations in recruitment is important to understanding how populations are maintained over time. Results of this study point to the role of several proximate environmental cues in determining the monthly patterns of tropical brachyuran larval abundance and 
Table 4. Cross-correlations between zoeal/megalopal abundances and wind and currents. Autoregressive moving average (ARMA) models were fitted to the physical parameters and abundance data. The residuals from these models were used in crosscorrelation analysis. All correlation coefficients presented are significant at $p<0.05$, unless otherwise noted (ns: not significant). Values in parentheses represent the lag in days. Values are in bold where correlations were consistent between deployments. Current meter deployment 1: Days 133 to 214, and current meter deployment 2: Days 236 to 317

\begin{tabular}{|c|c|c|c|c|c|}
\hline & $\begin{array}{c}\text { First-stage } \\
\text { zoeae }\end{array}$ & $\begin{array}{l}\text { Majidae } \\
\text { postlarvae }\end{array}$ & $\begin{array}{l}\text { Xanthidae } \\
\text { postlarvae }\end{array}$ & $\begin{array}{l}\text { Grapsidae } \\
\text { postlarvae }\end{array}$ & $\begin{array}{l}\text { Portunidae } \\
\text { postlarvae }\end{array}$ \\
\hline \multicolumn{6}{|l|}{ Wind } \\
\hline $\mathrm{E} / \mathrm{W}(\mathrm{m} / \mathrm{s})$ & $0.16(0)$ & $0.17\{0\}$ & $0.14(0)$ & ns & ns \\
\hline $\mathrm{N} / \mathrm{S}(\mathrm{m} / \mathrm{s})$ & $-0.19(-5)$ & $-0.21(-5)$ & $-0.16(-5)$ & ns & ns \\
\hline \multicolumn{6}{|c|}{ Currents: Deployment 1} \\
\hline $\begin{array}{l}\text { E/W Tidal } \\
\text { transport }\end{array}$ & ns & ns & ns & ns & ns \\
\hline $\begin{array}{l}\text { N/S Tidal } \\
\text { transport }\end{array}$ & ns & ns & ns & $-0.29(-5)$ & $-0.27(-5)$ \\
\hline $\begin{array}{l}\text { E/W Large- } \\
\text { scale transport }\end{array}$ & ns & ns & ns & $-0.22(4)$ & $\mathrm{ns}$ \\
\hline $\begin{array}{l}\text { N/S Large- } \\
\text { scale transport }\end{array}$ & $-0.24(3)$ & ns & $-0.24(-3)$ & $-0.23(1)$ & ns \\
\hline Currents: Deplc & & & & & \\
\hline $\begin{array}{l}\text { E/W Tidal } \\
\text { transport }\end{array}$ & ns & ns & $0.23(-1)$ & $-0.22(-5)$ & ns \\
\hline $\begin{array}{l}\text { N/S Tidal } \\
\text { transport }\end{array}$ & ns & ns & ns & $-0.28(6)$ & ns \\
\hline $\begin{array}{l}\text { E/W Large- } \\
\text { scale transport }\end{array}$ & ns & $0.27(-4)$ & ns & $0.31(2)$ & $-0.30(1)$ \\
\hline scale transport & ns & ns & ns & ns & ns \\
\hline
\end{tabular}

postlarval settlement. Cyclical environmental cues such as the lunar, tidal, light-dark, and tidal amplitude cycles appear to exert more influence on the production and settlement of these brachyuran species than do episodic or large-scale oceanographic processes.

\section{Temporal periodicity in larval abundance and postlarval settlement}

Zoeal abundance of brachyuran crustaceans at Barbados was continuous throughout the sampling interval. In tropical regions, minimal annual temperature fluctuations favor continuous reproduction. Growth rates remain relatively high throughout the year and elevated temperatures shorten the incubation period of brachyuran eggs (e.g. Jamaican majids had a $12 \mathrm{~d}$ incubation period compared to the $15 \mathrm{wk}$ period of a similar British species, Hartnoll 1965). Although production of the intertidal ocypodid Uca rapax in Panama ceased during the dry season, it was postulated that this seasonal pattern resulted from the drying of the sediment in which $U$. rapax lives (Morgan \& Christy 1994). Continuous production has been documented for a number of other tropical crustaceans (e.g. Jamaican mysids, Goodbody 1965; the Jamaican majids, Macrocoeloma tripinosum, Microphrys bicor- nutus, Mithrax sculptus, and Stenorhynchus seticornis, Hartnoll 1965; crustacean zooplankton at Barbados, Moore \& Sander 1977, the portunid Callinectes arcuatus in Central America, DeVries et al. 1983; and the Panamanian grapsid Pachygrapsus transversus, Morgan \& Christy 1994). Likewise, Epifanio \& Dittel (1984) reported that brachyuran larvae in a Costa Rican estuary were present year-round.

Temporal settlement of postlarval brachyurans to Barbados varied by family, but for the majority of families collected, was characterized by a large spring pulse, followed by a drop in abundance during the summer months, and a subsequent increase in the fall months. It is possible that settlement patterns reflect variable family-specific production patterns that are not discernable from our measure of first-stage zoeae. Seasonal variation in settlement, however, is unlikely a result of seasonally shifting environmental cues. Although proximate environmental cues are important factors influencing monthly patterns of larval abundances and settlement (see below), and evidence for other species suggests that seasonality is related to seasonal shifts in the timing of such cues (Morgan \& Christy 1994), it is unlikely the case at Barbados. For instance, moonless ebb tides are the most important proximate environmental settlement cue to postlarval majids (see below), yet total nightly ebb hours during quarter moons increase during the summer months to 
a fall plateau (opposite of what would be expected for a summer low in settlement; Reyns 1998)

Among-family differences in settlement may also be due to family-specific behavior. The Majidae and Portunidae postlarvae exhibited different settlement patterns (e.g. while majids were characterized by regular settlement pulses during the fall, portunid settlement during those months was more sporadic). These differences may be the result of differences in swimming behavior by postlarvae as well as the specific vertical position of postlarvae in the water column. Portunid postlarvae have well-developed 'paddles' and are presumably more capable swimmers than other brachyuran postlarvae. Such swimming behavior during settlement may enable these crabs to utilize alternative mechanisms to re-enter the reef environment. In addition, temperate portunid postlarvae such as Callinectes sapidus are known to inhabit the neuston and are thus influenced by surface transport processes, while majid megalopae occur below the pycnocline and are influenced more by upwelling events (Shanks 1998).

\section{Monthly patterns of larval abundances and postlarval settlement}

Most brachyuran crabs in this study exhibited strong cyclical monthly patterns of zoeal abundance and postlarval settlement. The observed monthly variability in larval abundance and settlement is closely timed to several environmental parameters, including the lunar and tidal amplitude cycles. When these proximate environmental cues are further refined into nightly light-dark (e.g. moon-illuminated and moonless) and tidal phase parameters, clear associations are evident between these cues and the timing of larval abundance and settlement.

\section{First-stage zoeal abundances}

First-stage zoeae peaked during the first quarter moon and minimum amplitude tides. Larval abundances were aiso most strongly correlated with moonilluminated ebb hours, a measure of relative darkness combined with ebb tides. Larval release during nocturnal ebb tides has been well documented for a number of temperate estuarine and intertidal brachyurans (Forward 1987, Morgan 1995). However, most of these species must be exported from nearshore habitats and larval release is associated with new and full moons when maximum amplitude tides occur (reviewed in Morgan 1995). In subtropical regions (e.g. Gulf coast of the USA) where the maximum amplitude tidal cycle shifts with respect to the light-dark cycle, the timing of larval release may shift as well, becoming synchronized with minimum or intermediate amplitude tides (Morgan 1996). At Barbados, maximum amplitude tides do not appear to be as important in determining larval abundances. The abundance of first-stage zoeae was higher during intermediate to minimum amplitude tides, and unlike temperate estuarine brachyuran larvae, was negatively correlated with the maximum amplitude tidal range. Nocturnal maximum amplitude tides are thought to be the mechanism by which early zoeal stages are exported away from coastal habitats (Christy 1982, Forward 1987, Morgan \& Christy 1994, Morgan 1996). For estuarine species that live in an environment where planktivorous fishes are abundant, moving quickly away from this habitat is likely selectively advantageous (Christy 1982), and may be most efficient on ebbing maximum amplitude tides. For intertidal species, crabs must walk to the water's edge in order to release larvae. Higher tides enable females, often leaving the cover of burrows, to travel shorter distances to reach the water (Morgan 1995).

Although coral reefs house an abundance of planktivorous fishes (reviewed in Jones et al. 1991) and rapid offshore transport of zoeae is likely important to overall survival, the ambient flow regime at Barbados is more complex than the bi-directional flow in estuarine systems. So, while first-stage zoeae presumably utilize ebb tides to move offshore, maximum transport may not be restricted to spring tides in such an open coastal environment. Alternatively, first-stage zoeae may cue into intermediate to minimum amplitude tides to reduce the chances of being exported too far off the narrow continental shelf. Furthermore, a majority of the crabs collected in the light traps at Barbados are subtidal, reef-associated species, thus constraints on adult movements are likely less restrictive.

The use of ebb tides combined with relative moonlight (moon-illuminated ebb tides) by first-stage zoeae is not surprising given that many brachyurans release larvae at dusk or during the first few hours after dusk (reviewed in Morgan 1995). Zoeae may use phototaxis to ambient moonlight to enter the surface waters to avoid reef-based predators and to be ultimately transported offshore in ebbing waters. Indeed, positive phototaxis is common in many newly released benthic invertebrate larvae, including brachyuran crabs (reviewed in Young 1995). Thus, it may be important for some moonlight to be present at the time of larval release (i.e. lower correlation with hours of moonless ebb).

Zoeal abundance was weakly correlated to both components of the mean wind velocity, however this is difficult to interpret since abundance was not significantly correlated with tränsport due to tidal currents or large-scale flow. Tighter correlations may have been 
evident had we used data from a shallower depth bin in the cross-correlations. Unfortunately, these records were not available due to interference of the ocean's surface with the ADCP. It is expected that the wind influences currents to a depth of approximately $45 \mathrm{~m}$ at Barbados (as calculated by the Ekman depth equation; Pond \& Pickard 1983), however the influence at this depth is likely weak.

\section{Settlement}

Settlement of postlarval brachyurans to Barbados occurred during both quarter moons, but predominately during the third quarter moon and intermediate to minimum amplitude tides. For majids, settlement occurred on quarter and new moons because they are cueing to the hours of moonless ebb tide that peak on the quarter and new moons. This relationship is even tighter during periods when relative abundance is high (i.e. fall months: Days 230 to 330 ) as the correlation with moonless ebb tide increases to 0.47 ( $-1 \mathrm{~d}$ lag; N. R. unpubl. data). Another environmental parameter with a third quarter moon pattern is hours of darkness, which was similarly (only slightly weaker) correlated with majid settlement. Although the use of ebb tides by postlarvae is counter to the accepted re-invasion strategies used by estuarine crabs (e.g. blue crabs: Epifanio 1988b, Tankersley et al. 1995, Forward et al. 1997), negative correlations between megalopal influx and dark flood tides have been observed elsewhere (along the coast of North Carolina; D. Eggleston, NCSU pers. comm.). The use of ebb tides during settlement may be more common for species from open coastal areas where tidal ranges are small. Indeed, decapod megalopae were collected in abundance during ebbing tides along a British coast (Colman \& Segrove 1955). Ebb tides may be important to the return of postlarvae by transporting chemical cues from the reef to the megalopae offshore. Megalopae, which are influenced by a variety of chemical cues during settlement (Wolcott \& DeVries 1994, Welch et al. 1997, Gebauer et al. 1998), may track these cues to find nearshore settlement sites. Chemical cues may be particularly important for tropical reef species to ensure settlement to appropriate habitats. In fact, the importance of habitat-related chemical cues may be why standard settlement collectors were unsuccessful at collecting megalopae at Barbados. Shanks (1995b) postulated that megalopae returning to Pacific coastlines orient themselves shoreward by cueing into the sun's illumination. Other factors that have been observed to influence postlarval behavior-induced transport include temperature (e.g. thermoclines, McConnaughey \& Sulkin 1984), and estuarine cues such as turbulence (Tankersley \& Forward 1994), pressure and salinity (Tankersley et al. 1995). In this case, reefbased cues may be delivered to offshore postlarvae via ebb tides.

To move onshore, or 'upstream' on ebbing tides, postlarvae may actively swim horizontally. Active swimming by temperate megalopae has been recently observed in a Washington state estuary (Eggleston et al. 1998). The small tidal range and relatively low velocity of the tidal currents at Barbados may make swimming a feasible mechanism by which megalopae return to nearshore habitats. Alternatively, several physical processes may facilitate passive onshore transport. For instance, internal waves and tidal bores (generated by breaking internal waves) have been implicated in larval transport along the west coast of the United States (see Shanks 1985, 1995a for review). Internal tidal bores are associated with tidal currents and may exhibit lunar periodicity (Pineda 1995), thus, regularly transferring neustonic larvae, nutrients, and suspended particles from offshore waters to the nearshore environment (Leichter et al. 1996). Although internal tides are generally poorly phase-locked with the baratropic tide (H. Peters, RSMAS pers. comm.), periodic cross-shelf transport of crab larvae by such physical processes has been demonstrated recently in the Florida Keys (Leichter et al. 1998), and evidence from the raw current meter records at Barbados suggest that internal tides may be fairly common in this region as well ( $\mathrm{K}$. Lwiza, SUNY at Stony Brook pers. comm.). Therefore, in response to nearshore settlement (chemical) cues flowing offshore on ebb tides, megalopae may actively swim or be transported onshore by internal tides.

The maximum daily tidal range does not appear to influence majid settlement as determined by the negative relationship between these 2 parameters. Although majids generally settle on intermediate to minimum amplitude tides, a combination of ebb tides and darkness appear to cue this settlement pattern rather than solely tides. Indeed, Shanks (1998) found no significant tidal influence on settlement of a temperate coastal, subtidal majid species.

Settlement of other postlarvae to Barbados, however, was most correlated with the maximum daily tidal range. Both the Xanthidae and Grapsidae postlarvae were negatively correlated with the maximum tidal range with a several day lag, consistent with settlement during intermediate to minimum amplitude tides. Relative darkness does not play a role in the timing of settlement. At this time, it is unknown why relative darkness is less important for these taxa, although certainly the singular importance of tides is evident in other behaviors of these species. For instance, the timing of larval release for grapsids (which are generally 
intertidal) and some xanthids is cued to the tidal cycle, with production occurring on maximum amplitude tides (Forward 1987, Morgan \& Christy 1994).

The settlement of all postlarvae was weakly correlated with the influence of wind. This relationship is not unusual given that postlarvae at Barbados are generally found at depth (N. R. \& Cowen unpubl. data). In addition, patterns of wind over the duration of the study did not vary significantly, even when tropical storms and hurricanes passed nearby (although always north of Barbados; N. R. pers. obs.).

Settlement also was not strongly related to any component of the tidal or large-scale flow measured by the current meter. Although Grapsidae postlarvae were negatively correlated with the north-south tidal transport during each current meter deployment, the lags were opposing between deployments. However, the oceanography surrounding Barbados is complex, with evidence of periodic low-salinity intrusions and eddies influencing the area during the study period (Kelly et al. in press). This complexity may contribute to the noise exhibited in the current meter record and the lack of significant correlations between patterns of settlement and various components of the flow regime. Because of this variability, however, brachyuran crabs at oceanic islands such as Barbados may have become adapted to more predictable environmental cues involving the tidal and light-dark cycles. In fact, at Barbados, brachyuran crabs appear to be using similar proximate environmental cues as reef fishes at settlement (Sponaugle \& Cowen 1996a, 1997). A diversity of fishes collected in light traps also settle to nearshore reefs during the third quarter moon and minimum amplitude tides (Sponaugle \& Cowen 1996a, 1997).

In summary, the overall abundance of larval brachyuran crabs at Barbados cycles with the periodicity of moon-illuminated ebb tides. As a result, firststage zoeae peak during the first quarter moon and minimum amplitude tides. Because larval abundances are associated with minimum amplitude tides, and because east-west tidal flow is minimal with respect to the north-south flow, transport offshore may be limited to just of of the nearshore reefs or within the fringing bank reef offshore. The strongly flowing north-south component of the currents may then entrain larvae causing them to 'swash' up and down the coast during development. Once competence is attained, subtidal megalopae (i.e. majids) may detect reef-based cues from ebb tides and either swim onshore actively during intermediate to minimum amplitude tides or may be transported across the narrow shelf distance by cyclical oceanographic processes. Settlement occurs on relatively dark ebb tides during the third quarter moon and minimum amplitude tides. For intertidal or subtidal species found just below the low tide water line (i.e. grapsids, and some xanthids), relative darkness appears to be less important and entrainment of the tidal amplitude cycle likely determines the pattern of settlement.

Further work is needed to couple offshore larval distributions with nearshore patterns of production and settlement to understand the timing of reproduction and the pelagic life cycle of tropical brachyuran crabs. Additional data on the vertical positioning of larvae in the water column, coupled with concurrent physical measurements will enhance our understanding of the biological and physical mechanisms governing the recruitment dynamics of tropical brachyurans.

Acknowledgements. This manuscript was greatly improved by the critical comments of R. Cowen, S. Morgan, and 2 anonymous reviewers. L. Dorsey graciously sewed light trap nets, and the following people helped with some aspect of light tran assembly: R Cowen, S. Dorsey, I Grothues, C. Masterson, and F. Reyns. S. Dorsey assisted with field work, while K. Woody, I. Popple and H. Maggs helped when necessary. A. Thomas and L. Ngo assisted with laboratory work, and B. Steves with some aspects of the data analysis. K. Lwiza and $\mathrm{P}$. Kelley assisted with the analysis of the current meter data, while R. Cerrato, S. Smith, and H. Deferrari provided statistical advice. S. Morgan made his library of larval descriptions available for species identifications. Facilities in Barbados were made available by the staff at Bellairs Research Institute of McGill University. Funding was provided by a National Science Foundation grant (OCE-9521104) to R. Cowen, K. Lwiza, and E. Schultz, and by a PADI Foundation grant to S.S. This represents contribution number 1154 from the Marine Sciences Research Center.

\section{LITERATURE CITED}

Acosta CA, Matthews TR, Butler MJ (1997) Temporal patterns and transport processes in recruitment of spiny lobster (Panulirus argus) postlarvae to South Florida. Mar Biol 129:79-85

Barnwell FH (1976) Variation in the forms of the tide and some problems it poses for biological timing systems. In: DeCoursey PJ (ed) Biological rhythms in the marine environment. Belle W. Baruch Institute Library in Marine Science, No. 4, University of South Carolinct Press, Columbia, p $161-187$

Batschelet E (1981) Circular statistics in biology. Academic Press, New York

Black KP, Moran PJ (1991) Influence of hydrodynamics on the passive dispersal and initial recruitment of larvae of Acanthaster planci (Echinodermata: Asteroidea) on the Cirrat Barrier Reef. Mar Ecol Prog Ser 69:55-65

Bloomfield P (1976) Fourier analysis of time series: an introduction. John Wiley and Sons, New York

Booth DJ, Brosnan DM (1995) The role of recruitment dynamics in rocky shore and coral reef communities. In: Begon $M$, Fitter AH (eds) Advances in ecological research. Academic Press, San Diego, p 309-385

Botsford LW, Wickham DE (1975) Correlation of upwelling index and Dungeness crab catch. Fish Bull US 73: 901-907

Chatfield C (1989) The analysis of time series: an introduction, 4th edn. Chapman and Hall, New York 
Christy J (1982) Adaptive significance of semilunar cycles of larval release in fiddler crabs (genus $U_{C a}$ ): test of an hypothesis. Biol Bull 163:251-263

Christy J (1986) Timing of larval release by intertidal crabs on an exposed shore. Bull Mar Sci 39:176-191

Colman JS, Segrove F (1955) The tidal plankton over Stoupe Beck Sands, Robin Hood's Bay (Yorkshire, North Riding). J Anim Ecol 24:445-462

Cowen RK, Castro LR (1994) Relation of coral reef fish larval distributions to island scale circulation around Barbados, West Indies. Bull Mar Sci 54:228-244

Cronin TW, Forward RB Jr (1983) Vertical migration rhythms of newly hatched larvae of the estuarine crab, Rhithropanopeus harrisii. Biol Bull 165:139-153

DeVries MC, Epifanio CE, Dittel Al (1983) Reproductive periodicity in the tropical crab Callinectes arcuatus Ordway in Central America. Estuar Coast Shelf Sci 17:709-716

DeVries MC, Tankersley RA, Forward RB Jr, Kirby-Smith WW, Luettich RW (1994) Abundances of crab megalopae are associated with estuarine tidal hydrologic variables. Mar Biol 118:403-413

Dittel AI, Epifanio CE, Chavarria JB (1985) Population biology of the portunid crab Callinectes arcuatus Ordway in the Gulf of Nicoya, Costa Rica, Central America. Estuar Coast Shelf Sci 20:593-602

Dunstan FDJ (1993) Time series analysis. In: Fry JC (ed) Biological data analysis: a practical approach, 1st edn. Oxford University Press, New York, p 243-310

Eggleston DB, Armstrong DA (1995) Pre- and post-settlement determinants of estuarine Dungeness crab recruitment. Ecol Monogr 65:193-216

Eggleston DB, Armstrong DA, Elis WE, Patton WS (1998) Estuarine fronts as conduits for larval transport: hydrodynamics and spatial distribution of Dungeness crab postlarvae. Mar Ecol Prog Ser 164:73-82

Epifanio CE (1988a) Dispersal strategies of two species of swimming crab on the continental shelf adjacent to Delaware Bay. Mar Ecol Prog Ser 49:243-248

Epifanio CE (1988b) Transport of invertebrate larvae between estuaries and the continental shelf. Trans Am Fish Soc Symp Ser 3:104-114

Epifanio CE, Dittel AI (1984) Seasonal abundance of brachyuran crab larvae in a tropical estuary: Gulf of Nicoya, Costa Rica, Central America. Estuaries 7:501-505

Epifanio CE, Valenti CC, Pembroke AE (1984) Dispersal and recruitment of blue crab larvae in Delaware Bay, U.S.A. Estuar Coast Shelf Sci 18:1-12

Epifanio CE, Little KT, Rowe PM (1988) Dispersal and recruitment of fiddler crab larvae in the Delaware River estuary. Mar Ecol Prog Ser 43:181-188

Forward RB Jr (1987) Larval release rhythms of decapod crustaceans: an overview. Bull Mar Sci 41:165-176

Forward RB Jr, Swanson J, Tankersely RA, Welch JM (1997) Endogenous swimming rhythms of blue crab, Callinectes sapidus, megalopae: effects of offshore and estuarine cues. Mar Biol 127:621-628

Gaines SD, Bertness MD (1992) Dispersal of juveniles and variable recruitment in sessile marine species. Nature 360 : 579-580

Gebauer P, Walter I, Anger K (1998) Effects of substratum and conspecific adults on the metamorphosis of Chasmagnathus granulata (Dana) (Decapoda, Grapsidae). J Exp Mar Biol Ecol 223:185-198

Goodbody I (1965) Continuous breeding in populations of two tropical crustaceans, Mysidium colombiae (Zimmer) and Emerita portoricensis (Schmidt). Ecology 46:195-197

Goodrich DM, van Montfrans J, Orth RJ (1989) Blue crab megalopal influx to Chesapeake Bay: evidence for a winddriven mechanism. Estuar Coast Shelf Sci 29:247-260

Hartnoll RG (1965) The biology of spider crabs: a comparison of British and Jamaican species. Crustaceana 9:1-16

Jassby AD, Powell TM (1990) Detecting changes in ecological time series. Ecology 71:2044-2052

Johnson DR (1985) Wind-forced dispersion of blue crab larvae in the Middle Atlantic Bight. Cont Shelf Res 4:733-745

Jones GP, Ferrell DJ, Sale PF (1991) Fish predation and its impact on the invertebrates of coral reefs and adjacent sediments. In: Sale PF (ed) The ecology of fishes on coral reefs. Academic Press, San Diego, p 156-179

Kelly PS, Lwiza KMM, Cowen RK, Goni GJ (in press) Lowsalinity lenses at Barbados, West Indies: their origin, frequency and variability. J Geophys Res

Leichter JJ, Wing SR, Miller SL, Denny MW (1996) Pulsed delivery of subthermocline water to Conch Reef (Florida Keys) by internal tidal bores. Limnol Oceanogr 41: $1490-1501$

Leichter JJ, Shellenbarger G, Genovese SJ, Wing SR (1998) Breaking internal waves on a Florida (USA) coral reef: a plankton pump at work? Mar Ecol Prog Ser 166:83-97

Lewis JB, Snelgrove PVR (1990) Corallum morphology and composition of crustacea cryptofauna of the hermatypic coral Madracis mirabilis Mar Biol 106:267-272

McConaugha JR, Johnson DF, Provenzano AJ, Maris RC (1983) Seasonal distribution of larvae of Callinectes sapidus (Crustacea; Decapoda) in waters adjacent to Chesapeake Bay. J Crust Biol 3:582-591

McConnaughey RA, Sulkin SD (1984) Measuring the effects of thermoclines on the vertical migration of larvae of Callinectes sapidus (Brachyura: Portunidae) in the laboratory. Mar Biol 81:139-145

Moore E, Sander F (1977) A study of the offshore zooplankton of the tropical Western Atlantic near Barbados. Ophelia 16:77-96

Morgan SG (1995) The timing of larval release. In: McEdward $\mathrm{L}$ (ed) Ecology of marine invertebrate larvae. CRC Press, Boca Raton, FL, p 157-191

Morgan SG (1996) Influence of tidal variation on reproductive timing. J Exp Mar Biol Ecol 206:237-251

Morgan SG, Christy JH (1994) Plasticity, constraint and optimality in reproductive timing. Ecology 75:2185-2203

Olmi EJ III (1994) Vertical migration of blue crab, Callinectes sapidus megalopae: implications for transport in estuaries. Mar Ecol Prog Ser 113:39-54

Paine RT, Levin SA (1981) Intertidal landscapes: disturbance and the dynamics of pattern. Ecol Monogr 51:145-178

Pineda J (1995) An internal tidal bore regime at nearshore stations along western USA: predictable upwelling with the lunar cycle. Cont Shelf Res 15:1023-1041

Pond S, Pickard GL (1983) Introductory dynamical oceanography, 2nd edn. Pergamon Press, Oxford

Provenzano AJ Jr, McConaugha JR, Philips KB, Johnson DF, Clark J (1983) Vertical distribution of first stage larvae of the blue crab, Callinectes sapidus, at the mouth of Chesapeake Bay. Estuar Coast Shelf Sci 16:489-499

Rabalais NN, Burditt FR Jr, Coen LD, Cole BE, Eleuerius C, Heck KL Jr, McTigue TA, Morgan SG, Perry HM, Truesdale FM, Zimmer-faust RK, Zimmerman RJ (1995) Settlement of Callinectes sapidus megalopae on artificial collectors in four Gulf of Mexico estuaries. Bull Mar Sci 57: $855-876$

Reed JK, Gore RH, Scotto LE, Wilson KA (1982) Community composition, structure, areal and trophic relationships of decapods associated with shallow- and deep- water Oculina varicosa coral reefs: studies on the decapod crus- 
tacea from the Indian River region of Florida, XXIV 1982. Bull Mar Sci 32:761-786

Reyns N (1998) Recruitment dynamics of tropical brachyuran crustaceans. Master's thesis, State University of New York at Stony Brook, Stony Brook, New York

Sebens KP (1984) Biodiversity of coral reefs: what are we losing and why? Am Zool 34:115-133

Shanks AL (1985) Behavioral basis of internal wave-induced shoreward transport of megalopae of Pachygrapsus crassipes. Mar Ecol Prog Ser 24:289-295

Shanks AL (1995a) Mechanisms of cross-shelf dispersal of larval invertebrates and fish. In: McEdward L (ed) Ecology of marine invertebrate larvae. CRC Press, Boca Raton, FL, p 323-367

Shanks AL (1995b) Orientated swimming by megalopae of several eastern North Pacific crab species and its potential role in their onshore migration. J Exp Mar Biol Ecol 186: $1-16$

Shanks AL (1998) Abundance of postlarval Callinectes sapidus, Penaeus spp., Uca spp., and Libinia spp. collected at an outer coastal site and their cross-shelf transport. Mar Ecol Prog Ser 168:57-69

Sponaugle S, Cowen RK (1996a) Nearshore patterns of coral reef fish larval supply to Barbados, West Indies. Mar Ecol Prog Ser 133:13-28

Sponaugle S, Cowen RK (1996b) Larval supply and patterns of recruitment for two Caribbean fishes, Stegastes partitus and Acanthurus bahianus. Mar Freshw Res 47:433-447

Sponaugle S, Cowen RK (1997) Early life history traits and recruitment patterns of Caribbean wrasses (Labridae). Ecol Monogr 67:177-202

Stansfield KL (1995) Coastal ocean circulation around the island of Barbados, West Indies. PhD dissertation, State University of Vew York, Stony Brook, New York

Stoner AW, Smith NP (1998) Across-shelf transport of gastropod larvae in the central Bahamas: rapid responses to local wind conditions. J Plankton Res 20:1-16

Stoner AW, Mehta N, Lee TN (1997) Recruitment of Strombus veligers to the Florida Keys Reef Tract: relation to hydrographic events. J Shellfish Res 16:1-6

Tankersley RA, Forward RB Jr (1994) Endogenous swimming

Editorial responsibility: Otto Kinne (Editor),

Oldendort/Luhe, Germany rhythms in estuarine crab megalopae: implications for flood-tide transport. Mar Biol 118:415-423

Tankersley RA, McKelvey LM, Forward RB Jr (1995) Responses of estuarine crab megalopae to pressure, salinity and light: implications for flood-tide transport. Mar Biol 122:391-400

van Montfrans J, Peery CA, Orth RJ (1990) Daily, monthly and annual. settlement patterns by Callinectes sapidus and Neopanope sayi megalopae on artificial collectors deployed in the York River, Virginia: 1985-1988. Bull Mar Sci 46:214-229

van Montfrans J, Epifanio CE, Knott DM, Lipcius RN, Mense DJ, Metcaif KS, Olmi EJ III, Orth RJ, Posey MH, Wenner EL, West TL (1995) Settlement of blue crab postlarvae in western north Atlantic estuaries. Bull Mar Sci 57:834-854

Welch JM, Rittschof D, Bullock TM, Forward RB Jr (1997) Effects of chemical cues on settlement behavior of blue crab Callinectes sapidus postlarvae. Mar Ecol Prog Ser 154:143-153

Wing SR, Largier JL, Botsford LW, Quinn JF (1995) Settlement and transport of benthic invertebrates in an intermittent upwelling region. Limnol Oceanogr 40:316-329

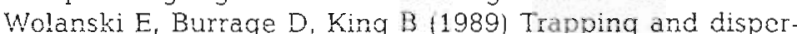
sion of coral eggs around Bowden Reef, Great Barrier Reef, following mass coral spawning. Continental Shelf Res 9:479-496

Wolcott DL, DeVries MC (1994) Offshore megalopae of Callinectes sapidus: depth of collection, molt stage and response to estuarine cues. Mar Ecol Prog Ser 109:157-163

Yeung $C$ (1996) Transport and retention of lobster phyllosoma larvae in the Florida Keys. PhD dissertation, University of Miami, Coral Gables, Florida

Young CM (1995) Behavior and locomotion during the dispersal phase of larval life. In: McEdward L (ed) Ecology of marine invertebrate larvae. CRC Press, Boca Raton, FL, p 249-277

Zar JH (1984) Blostatistical analysis Prentice-Hall, Englewood Cliffs, NJ

Zeng C, Naylor E (1996) Occurrence in coastal waters and endogenous tidal swimming rhythms of late megalopae of the shore crab Carcinus maenas: implications for inshore recruitment. Mar Ecol Prog Ser 136:69-79

Submitted: October 15, 1998; Accepted: March 29, 1999

Proofs recelved from author(s): August 5, 1999 